\title{
Investigation of Performance Management System and its Effectiveness with Special Reference to Garment Factories in Katunayake Export Processing Zone in Sri Lanka
}

\author{
K. A. K. S. Rathnakara ${ }^{1}$ and B. J. H. Arachchige ${ }^{2}$ \\ ${ }^{1}$ Horizon Campus, Sri Lanka \\ ${ }^{2}$ Department of Human Resource Management, Faculty of Management Studies and \\ Commerce, University of Sri Jayewardenepura, Sri Lanka \\ ${ }^{1}$ sakurathnakara@gmail.com, ${ }^{2}$ bhadra@sjp.ac.lk
}

\begin{abstract}
Performance management deals with identifying, measuring and developing performance of individuals, groups and teams and aligning performance with the strategic goals of the organization with the ultimate objective of improving organizational performance. This research was conducted with special reference to large scale garment factories in the Katunayake Export Processing Zone in Sri Lanka. The main objective of the study was to investigate the effectiveness of the performance management system with the implications of a systematic process of managing employee performance. Data were collected from managerial and executive level employees of the selected garment sector organizations. A structured questionnaire developed by the researcher was used to collect data the sample was selected using convenient sampling method. Hypotheses testing was used to complete the research study and Sixty seven participants have responded with a forty two percent response rate. Statistical Package for Social Sciences (SPSS 21) was utilised as the statistical tool to analyse data. Findings of the research suggested that the effectiveness of the performance management system is at an effective level and the components of the performance management system; planning performance, monitoring performance, reviewing performance, improving performance and managing unsatisfactory performance are positively related with the effectiveness of the performance management system. Furthermore, it was found that monitoring and reviewing performance are the most critical variables which determine the effectiveness of performance management system. In addition to these findings, slight variations between managers and executive employees were found in terms of perception on the same performance management system.
\end{abstract}

Keywords: Performance Management (PM), Effectiveness of Performance Management System

\section{Introduction}

Organizations are influenced by the challenging global economic conditions to focus more on their internal performance and productivity gains rather than focusing on the external market opportunities.
Consequently, emphasis on internal strengths was reinforced with the 'Resource based View' approach. This notion was further endorsed by Wrigth, Dunford and Snell (2001) with the idea of obtaining sustainable competitive 
advantage through focusing more on internal strengths. With this approach the human resource tended to be considered as one of the strategic resources which is rare, valuable, inimitable, and non-substitutable and can provide sources of sustainable competitive advantages (Barney, 1986). Further, to this idea Wrigth, et $a l$. , (2001) mention the two types of approaches for obtaining competitive advantage through human resource. One argument is on human reosurce as a source of sustainable competitive advantage whereas the other one is considering human resource practices of an organization as a source of competitive advantage. Aligning with this approach, Lado and Wilson (1994) have proposed that sustainable competitive advantage can be achieved through human resource practices whereas human resource systems cannot be imitated due to the uniqueness, ambiguous and synergetic nature of the systems whereas others focus on just the human resource (Wrigth, et al., 2001).

Smith and Rupp (2002) also identify human capital as an essential element for sustainable competitive advantage and thus it is indispensable to focus on the way they are managed. The critical need of streamlining the human resource outcomes with company vision, mission and strategies led the organizations to put more emphasis on improving employee performance (Schuler and Jackson, 2005). In this background, the High Performance Work System (HPWS) concept also came into consideration and it is identified as a key strategic lever to develop and sustain core competencies and as an essential requirement for strategy implementation. Furthermore, Huselid (1995) mentions these 'high performance work systems' consist of rigorous recruitment and selection protocols, performance management and incentive compensation systems and employee training and development activities which are designed to facilitate acquisition and reinforcing employee skills and behaviors which are required for the implementation of the firm's competitive strategy. With this trend, the emphasis on performance management has gradually increased.

Performance management can be considered as a broad area of study which is essential to streamline the individual and team performance with the strategic goals and objectives of the organization. As defined by Agunis (2009), performance management is 'a continuous process of identifying, measuring and developing the performance of individuals, groups and teams aligned with strategic goals of the organization'.

As stated by Castke et al. (2003), the main objective of performance management is to ensure the integrated nature of all subsystems of the organization to achieve their ultimate objectives. Several scholars have identified the significance of performance management for the organizations for ensuring the overall effectiveness (DeNiSi, 2011; Dewettinck \& Dijk, 2013; Tovey, et al. , 2010; Rashidi, 2015) as it leads the organization towards higher efficiency, effectiveness, profitability and quality of service. McDonald and Smith (1991) further endorse this argument as they have found that the organizations who are engeged in managing their 
employee performance are benefited with higher profit, cash flows and strong stock market performance (Armstrong, 2014). Also an effective performance management system will contribute to strengthern the relationship between all the parties involved with performance management (Shields et al, 2007).

\section{Research Problem}

The main objective of this study was to investigate the performance management system and its effectiveness with special reference to garment factories in Katunayake Export Processing Zone in Sri Lanka. As explained in the previous section, performance management has become one of the critical human resource management functions which is essential for any organization to streamline employee performance with their strategic and operational goals and objectives. The garment industry in Sri Lanka has been selected for the study based on several reasons. According to the Export Development Board (2016), the Sri Lankan apperal industry consists of three hundred (300) to three hundred and fifty (350) manufacturers who provide over three hundred thousand (300000) direct employment opportunities and six hundred thousand (600000) indirect employment opportunities which shows the comparatively significant contribution to the Sri Lankan economy.

The Sri Lankan apparel industry can be identified as a labour intensive industry and it is affected by the inherent issues of managing human resource (Lanarolle, et al., 2014). Lanarolle, Perera and Yapa (2014) further mention that, these factories are always target driven and highly concerned with managing employee performance aligned with their organizational performance targets. Similar to other labour intensive manufacturing industries, the apparel industry also incurs a huge cost on human resource (basically for salaries). As menitoned by Kelegama and Epaarachchi (2003), the labour cost in the apparel sector has spent is around fifteen point five percent of their total revenue in 1998.

With the expansion of the Sri Lankan apparel sector it was inevitable it will experience several issues continuously due to the inherent features of the industry. One of the main causes was the major and critical role played by human resource (Kottawatta, 2007). As mentioned by Kottawatta (2007), the apparel industry had to face human resource related issues such as high labour turnover and absenteeism which was having a direct impact on overall productivity of the organization. Allen (2008) posits that managing employee performance has become more challenging due to a lack of devotion among the industry on managing and maintaining the performance improvement (Lanarolle, et al., 2014). They further explain that most of the firms have to experience significant loss of time, money and effort with a lower level of success caused by lack of consideration on practical applicability and capability and compatibility of the wellknown performance improvement philosophies.

Employee performance management has become one of the major determinants of overall organizational performance and it is validated by a 
study conducted by Hussain Ali and Opatha (2008) with reference to the apperal industry in Sri Lanka. They have found a significant positive relationship between percieved systematic use of performance appraisal and percieved degree of business performance of apperal firms in Sri Lanka. Based on the studies, application of an effective performance management system will be an added value for these garment sector organizations. But, irrespective of the significance of performance management, some of these organizations perceive the typical annual performance evaluation process is adequate to control and improve employee performance. Hence, the main focus of this research is to investigate to what extent a performance management system is effective and the contribution of performance management practices for ensuring the effectiveness of the system. Then the recommendations can be provided based on the findings of the study to the garment industry in Sri Lanka, regarding the practices which have a significant effect on the effectiveness of the overall performance management system.

The main focus of this study was to investigate the existing performance management systems of the garment industry organizations and the system effectiveness. Based on that, the relationship between the performance management system and the effectiveness of the system were investigated. Hence, the problem of the study was as follows.

Is performance management systems effective in the garment factories in Katunayake Export Processing Zone

Kelaniya Journal of Human Resource Management in Sri Lanka, and is there a relationship between performance management system and its effectiveness?

\section{Objectives of the Study}

The main objective of this study was to investigate the effectiveness of the performance management systems and the relationship between performance management system and its effectiveness in garment factories in the Katunayake Export Processing Zone in Sri Lanka. Specific objectives of the study were as follows.

- $\quad$ To assess the relationship between performance planning and effectiveness of the performance management system.

- $\quad$ To assess the relationship between performance monitoring and effectiveness of the performance management system.

- $\quad$ To assess the relationship between performance reviewing and effectiveness of the performance management system.

- To assess the relationship between the availability of measures to improve performance and effectiveness of the performance management system.

- $\quad$ To assess the relationship between the availability of mechanisms for managing unsatisfactory performance and effectiveness of the performance management system. 


\section{Literature Review}

\section{Performance Management Systems}

Armstrong (2015) defines performance management system as 'a set of interrelated activities and processes which are treated as an integrated and key component of an organization's approach to managing performance through people and developing the skills and capabilities of its human capital'. Aligning with this idea, Boipono et al. (2014) have identified performance management system as a system that is used to enhance employee productivity through managing their performance. Dewettinck and Dijk (2013) explain the elements of a performance management system as performance standards, methods to measure and evaluate performance based on those standards, tools to improve performance, and feedback. Also referring to DeNisi (2000), they further mention that performance management system will consist of a range of activities engaged in by an organization to enhance the performance of a target group or a person and finally the organizational performance. Roberts (2003) identifies duration of formal performance reviews, the frequency of informal performance reviews, performance review focus and the degree of participation in decision making as the elements of a performance management system and he has linked these elements with the performance management practices. Hence it can be mentioned that performance management system consists of step by step process of managing performance. Based on this argument, the researcher has concluded that performance management can be referred as a collection of processes involved with managing performance.

\section{Theories Undepinning Performance Management}

Theoritical roots of performance management go back to several motivational theories. As mentioned by Buchner (2007), traditional performance management processes mainly focus on managerial objectives and it is not favourable in performers' perspective. However Buchner (2007) emphasizes the relevance of motivational theories in developing proper performance management system. He identifies Goal-Setting theory introduced by Locke and Latham in 1990, Control theory by Carver and Scheier (1998) and Social cognitive theory by Donovan which underpin the concept of performance management.

\section{Characteristics of an Effective Performance Management System}

As described by Aguinis (2009), an effective performance management systems will consist of several features as strategic congruence, thoroughness, practicality, meaningful, specific, identification of effective and ineffective performance, reliabilty, validity, fairness, clear communication, correctability, standardization and ethicality. Armstrong (2006) also suggests some critical characteristics of performance management as concerned with inputs and values, a continuous and flexible process which involves managers and 
those whom they manage acting as partners within a framework that sets out how they can best work together to achieve the required results. Further he mentions an effective performance management system focuses on future performance planning and improvement rather than on retrospective performance appraisal and a continuous and evolutionary process, in which performance improves over time. As cited by Ammons and Roenigk (2015), literature on performance management (Behn, 2002; Heinrich, 1999; Moynihan, 2008; Sanger, 2008; Schick, 2002; Damanpour, and Devece, 2011) suggests that effective performance management system should consist of several characteristics. The system should clarify the goals clearly and greater emphasis should be directed on results or outcomes than on inputs and procedural compliance, engagement of executive and legislative officials in relation with priority setting, monitoring performance reports and feedback should be ensured and the top management intervention in operating decisions should be limited and operating decisions should be made by the department and sectional level.

\section{Process of Performance Management}

Armstrong (2009) identifies performance management as a cycle consists of planning, acting, reviewing and monitoring where the process is continuous and ongoing. As Tovey (2001) posits, performance management consists of mainly three steps: planning performance, performance management and reviewing performance. In addition to these main three stages, improving performance and managing unsatisfactory performance are considered as another two steps. According to Aguinis (2009), performance management process consists of six steps: identifying prerequisites, performance planning, performance execution, performance assessment, performance review and performance renewal and recontracting.

\section{Determinants of the Effectiveness of Performance Management Systems}

Effectiveness of a performance management system can be defined as 'the degree to which the system delivers its intended results and simply helping organizations to plan, measure and control their performance' (Bento and Bento, 2006). Different researchers have conducted a variety of studies in relation to the relationship between organizational contextual variables such as organizational culture, employee engagement, fairness, psychological contract, employee attitudes, employee behavior, employee satisfaction, employee loyalty and the effectiveness of performance management system ( Stiles et al. , 2007; Rao, 2007; Robbins and Charbonneau, 2008; Kagaari and Ntayi, 2010; DeNisi, 2011; Kagaari, 2011; Dewettinck and Dijk, 2013, Jaksic and Jaksic, 2013; Rishipal and Manish, 2013; Qureshi and Hassan, 2013; Bawole, et al. , 2013; Clark, 2015). But, it can be noted that, there is a shortage of studies which have been conducted on the entire performance 
management system and the overall effectiveness of the system.

Kagaari, et al. (2010) have found a significant positive relationship between performance management practices and managed performance in public universities in Uganda. In his study, Kagaari (2011) posits that the results of the study confirmed that organizational culture and climate moderate the relationship between performance management practices and managed performance. In both of these studies (Kagaari, et al., 2010; Kagaari, 2011) agency relations, relevant resources, dynamic capability and goal setting were considered as the performance management practices. Referring to Kochanski (2007), Armstrong (2014) mentions Sibson and World at Work have found that leaders of high performing firms always support the performance management process. In addition to that, it was found that the firms which provided the highest total return for shareholders have implemented performance management systems which were rated as effective. Further it is mentioned that the companies who are maintaining effective performance management systems use their systems as the primary way to manage individual performance throughout the company, strong leadership support and have more line champions.

Dewettinck and Dijk (2013) propose performance management system effectiveness will be determined by employee motivation, better functioning, clarifying the expectations regarding functioning, enhancing selfesteem of employees, contribute to employee professional development, provide more insight into employee personal contribution and added value, effect on employee performance and provide clear insight into career opportunities of employees. Furthermore, Haines and St-Onge (2012) identify performance management system effectiveness will be affected by the system practices such as training for managers, employee recognition, multisource feedback and contextual practices such as organizational culture and strategic integration with organizational goals. Rao (2007) identifies four factors which directly effect on performance management system effectiveness as content variables (objectives, awareness, performance planning, etc.), process variables (feedback, review, grievance mechanism, etc.), output variables (rewards/recognition, development value, administrative value etc.) and organizational characteristic variables (support mechanism, facilitation for effect).

\section{Barriers to Effectiveness of Performance Management Systems and Strategies to Overcome the Barriers}

Rashidi (2015) identifies not setting specific goals and objectives, resistance to change, lack of training and inadequacy of resources as the most common barriers to ensure the effectiveness of the performance management. As posited by Tovey (2001), evaluating personality traits, bullying the staff, personal prejudices, ineffective feedback, managers' imcompetence in effective communication and effective listening and handling conflicts are some of the barriers which negatively influence the 
effectiveness of the performance management system. In addition, Armstrong (2014) specifically mentions about the issues faced by the organizations in relation to performance management systems which negatively affect the effectiveness of the system. One of the major issues is tendency of managers to inflate the ratings to avoid confrontation with the individuals concerned. In order to overcome the issue of inflating the ratings by the raters, some organizations have implemented forced distribution technique (Armstrong, 2014).

Shields et al. (2007) suggest that mostly common weaknesses of performance management processes are low rates of coverage, low quality conversations and non - existance of well planned follow-up. Referring to Duncan Brown (2010), Armstrong (2014) mentions human errors such as uncommitted directors, incompetent line managers and employees and complex and bureaucratics human resource processes are another set of barriers which restricts the effectiveness of performance management. Brown (2011) has also stated that it is essential to concern with skills and attitudes of reviewing managers, the consistency and quality of approach, quality of paperwork and the value of output of performance management system (Armstrong, 2014). According to Armstrong (2014), the e-reward survey of the performance management, the most common reasons for the failures are line managers are not having required set of skills, line managers' weaknesses in discriminating employees in relation with evaluating performance, lack of commitment of line managers for performance management and the reluctant nature of line managers to conduct performance management reviews.

\section{Performance Management Systems and Effectiveness}

According to Tovey (2010), a Performance Management system consists of main three phases: planning performance, monitoring performance and reviewing performance and finally performance should be improved as well as unsatisfactory performance should be managed. As Tovey (2010) explains, organizations can achieve the objectives of Performance Management though this process as it is more rigorous, clear and specific.

Planning performance is an essential element in the performance management process and it can be identified as 'a process of defining the organizational objectives, establishing an overall strategy for achieving these goals and developing a comprehensive hierarchy of plans to integrate and coordinate activities' (Tovey, 2010). It is recommended to develop strategic plans which consist of vision, mission, goals, objectives and the strategies of the organization and these goals should be cascaded down to the individual level. Performance measurements should be developed by aligning with the overall goals and objectives of the organization, as the predetermined goals and objectives are to be achieved through people. In this process, critical success factors and key performance indicators perform a major and critical role. Critical success factors can be identified as the issues and areas that 
are absolutely critical for an organization to address in achieving its plans (Tovey, 2010). Key performance indicators should be developed based on critical success factors and it is recommended to develop these critical success factors based on the opinions given by other stakeholders including customers, suppliers and employees rather than only relying on managers.

Operational plans should be developed in order to figure out the way of achieving the predetermined goals. It is indispensable to refer key performance indicators and critical success factors in developing operational plans since operational plans explain the means of achieving goals where the key performance indicators denote the specific results expected to be achieved. Operational plans become of utmost importance for implementing the strategies as the plans provide a comprehensive guide to how the organization should work and perform to deliver the end results required by the management.

As mentioned by Tovey (2001), managers are directly responsible for interpreting the strategic plans into tangible, workable, operational objectives and strategies in relation to resource utilization, delivering the product or service while achieving the allocated budget. Operational plans are utilized as a guidance for daily activities as well.

Setting standards based on the overall objectives of the organization is another essential requirement. In relation to this process, essentially critical success factors and key performance indicators need to be reviewed before setting performance standards. Standards needs to be valid and reliable which means the measure should be adequate to measure the actual result expected. On the other hand, standards should be set based on a mutual agreement between both employees and managers. Apart from that, standards should be realistic, measurable, clearly defined and linked with the strategies and operational plans. This sequential process can be identified as performance planning and this is the base for the entire performance management system. It can be noted that, this relationship is supported by previous studies as well. As suggested by Wong and Snel (2003), Rao (2007), Fox (2010), Daoanis (2012), Qureshi and Hassan (2013) as well as Dewettinck and Dijk (2013), setting performance standards and maintenace of proper and constructive communication with employees are positively related with the effectiveness of the performance management system. Furthermore, Dewettinck and Dijk (2013) and Chenhall (2005) emphasize the significance of fairness of planning performance to ensure the effectiveness of performance management.

After the completion of performance planning process, individual and team performance should be monitored systematically. The first requirement is studying performance standards. Tovey (2001) further suggests it is essential to encourage the employees on self-monitoring. The next requirement is to decide the evidence which should be collected and the time period and this entire process should be conducted in a non-judgmental way. 
The performance monitoring function is of utmost importance for ensuring the collection of accurate and timely evidence on employee performance where the success of the next step, reviewing performance, depends on the success of the monitoring process. Aligning with this framework, Komati and Zhou (2013) suggest that continuous monitoring and providing frequent constructive feedback directly affects the effectiveness of performance management. In line with these findings, Ferreira and Otley (2009), Biron, et al. (2011) and Mone, et al. (2011) further endorse this relationship by emphasizing the importance of ongoing monitoring and effective feedback.

After the completion of monitoring performance, collected evidence on employee performance should be reviewed. The reviewing performance step consists of two sub elements: performance analysis and performance appraisal. The main purpose of performance analysis is to check whether predetermined performance standards have been met or not. The difference between expected and actual performance should be identified and further, the reasons for these deviations should be identified. Performance analysis should be done in a systematic way as the accuracy of decisions made based on performance information will depend on the accuracy of analysis.

Performance should be appraised once after completing analyzing the performance and it is essential to establish a systematic method of appraising employee performance. Personal development plans can be developed based on the appraisal results in order to ensure the continual growth of the employees.

Performance management system should be adequate to clearly identify the skill gaps of the employees. It is essential to identify the problems related with employee performance, otherwise it will be difficult to solve employee performance related problems. The performance appraisal is not only about evaluation but also providing feedback as well. Performance appraisal step will not be completed if the organization has not discussed the results with the evaluee. Feedback can be identified as 'specific communication facilitated by the appraiser about the existing work performance and planning of the future performance of an individual' (Tovey, 2001). The main two dimenisons which should be considered are the frequency of feedback and process of communication. It is essential for organizations to decide the purpose of performance evaluation as a prerequisite of evaluating performance and that purpose should be communicated with the appraisee as well. This step is essential for planning performance for the future, to identify the performance requirements and career aspirations, deciding on pay increases, succession planning, employee motivation and to identify the training needs.

Mone, et al. (2011), Daoanis (2012) and Dewettinck and Dijk (2013) suggest that constructive and clear feedback should be provided based on the evaluation results. Aligning with these findings, Qureshi and Hassan (2013) have emphasized the significance of fair and timely 
appraisal for ensuring the effectiveness of performance management. These relationships are further endosed by Zvavahera (n.d.), Ferreira and Otley (2009) as well.

After the completion of reviewing performance, the management is in a position to understand the gap between actual performance and performance standards. This entire process is significant to understand the deviations from the standards. After appraising performance, it is essential to improve the performance as per the requirements. A proper mechanism should be established with the purpose of identifying the development needs based on the appraisal information. The main purpose of this step is to improve identified weak performance. In order to ensure the success of this step, it is essential to provide a thorough training for the appraiser in relation to communicating with employees and improving their performance. As a pre requisite, skill gaps and training needs should be clearly identified. After that, identified training needs should be categorized since it is not practical to fulfil each and every training need separately due to financial and other restrictions. Furthermore these needs should be linked with specific outputs.

Mone, et al. (2011) have found the significance of correctly identifying the skill gaps and providing training and development opportunities on the effectinvess of performance management. This finding is further endorsed by research studies conducted by Haines and St-Onge (2012), Buchner (2007) and Zvavahera (n.d.) where they have identified the contribution provided by constructive traning to improve the effectiveness of performance management.

A well planned performance management system should facilitate the process of managing unsatisfactory performance. The requirement for managing unsatisfactory performance occurs as the availability of employees who do not put any effort to improve their performance even after providing a personal development plan. It is essential to implement an appropriate mechanism to manage unsatisfactory performance which is important for both appraiser and employee. This process is of utmost importance for the organization to achieve its goals and objectives and for the employees for their career development and personal development.

The main components of managing unsatisfactory performance are collecting and analyzing evidence, appraise the evidence and planning for the improvement. Unsatisfactory performance should be managed based on a systematic process. There is a possibility of having different reasons for the poor performance and these reasons should be clearly identified. It is essential to document the unsatisfactory performance and after the documentation, performance counselling meetings should be arranged in order to discuss the performance issues with the employee. At the counseling meeting, employees will be provided opportunity to express their issues and clarifications.

It is found that effectiveness of performance management is effected by the way of managing unsatisfactory performance. Clark (2015) suggests 
that corrective actions should be taken to manage unsaisfactory performance and should be handled in a construtive manner. Furthermore, Martinez, et al. (2010) suggest that compensation should be properly aligned with performance in order to manage unsatisfactory performance while motivating employees. They further suggest that performance results should be utilized to decide the consequences and necessary actions should be taken to manage unsatisfactory performance in order to ensure the success of the performance management process. In line with these suggestions, Daoanis (2012) and Rashidi (2015) have indicated the necessity of taking actions to address the problems related with employee performance with the purpose of improving effectiveness of performance management.

\section{Garment Sector in Sri Lanka}

Due to the growing competition of the industry, the workload of the apparel sector employees was gradually increased (Sridarran, 2016). With the expansion of the Sri Lankan apparel sector, they had to face several issues continuously due to the inherent features of the industry. The main cause was the critical role played by human resources (Kottawatta, 2007). As mentioned by Kottawatta (2007), the apparel industry had to face human resource related issues such as high labour turnover and absenteeism which was having a direct impact on overall productivity of the organization.

Kelegama and Epaarachchi (2003) identify poor working conditions, poor incentives for workers, higher labour turnover, absenteeism, inadequate human resource development opportunities, strained employeremployee dialogue, restrictive labour regulations, lower investment in technology, slow turnaround time, poor garment factory standardization and lack of professionalism as the main and common causes for lower productivity. In additioin to that, most of the garment sector employees are facing issues such as sexual harrassemnet of female employees, longer working hours, no extra payment for additional working hours, continuous working in both shifts, requirements to work in night shifts and most of these issues are related to human resourse practices. Due to these human resource management issues, managing employee performance has become the main concern of the management. Inspite of thee most of the human resource managers try to streamline the human performance with the overall organizational goals and it has become a critical challenge.

As mentioned by Lanarolle, et al. (2014), achievement of results expected through performance improvement efforts is not been successful. Allen (2008) posits that the main reason for this failure is lack of devotion among the industry on managing and maintaining the performance improvement (Lanarolle, et al., 2014). They further explain that most of the firms have to experience significant loss of time, money and effort with a lower level of success caused by lack of consideration on practical applicability and capability and compatibility of the well known performance improvement philosophies. Apart from that several studies were conducted in relation to 
the impact of performance management and evaluation practices on business performance. Hussain Ali and Opatha (2008) have posited that there is a significant positive relationship between percieved systematic use of performance appraisal and percieved degree of business performance of apperal firms in Sri Lanka. So, these findings emphasize the significance of development, implementation and maintenance of an effective performance management system for garment sector organizations to achieve the expected employee performance as well as business performance.

\section{Materials and Methods}

Relevant information regarding the garment factories were gathered from Board of Investment (2016), Sri Lanka and according to their records, fourteen garment factories were established in the Zone. Based on the availability of the large scale key players in Katunayake export processing zone, three factories were selected as the sample for the study.

As the unit of study is individual employees, sample was selected based on the number of managers and executive level employees who were employed at these selected organizations. The total sample size was one hundred and sixty one employees. Sample of the managerial and executive employees were selected from the population through convenience sampling technique and questionnaires were sent to all the individuals in the selected factories (managers and executives).

A questionnaire developed by the author based on the framework introduced by Tovey (2010) was used to collect data on performance management system and the framework developed by Agunis (2009) was utilized to collect data on effectiveness of the performance management system.

\section{Conceptual Framework}

The objective of the study was to identify whether the performance management systems are effective in the garment factories located in Katunayake Export Processing Zone and the relationship between the elements of the system and the effectiveness of the system. In order to identify these relationships, the following framework was developed based on the literature. Five independent variables were identified as planning performance, monitoring performance, reviewing performance, improving performance and managing unsatisfactory performance where effectiveness of the performance management system was identified as the dependent variable. 


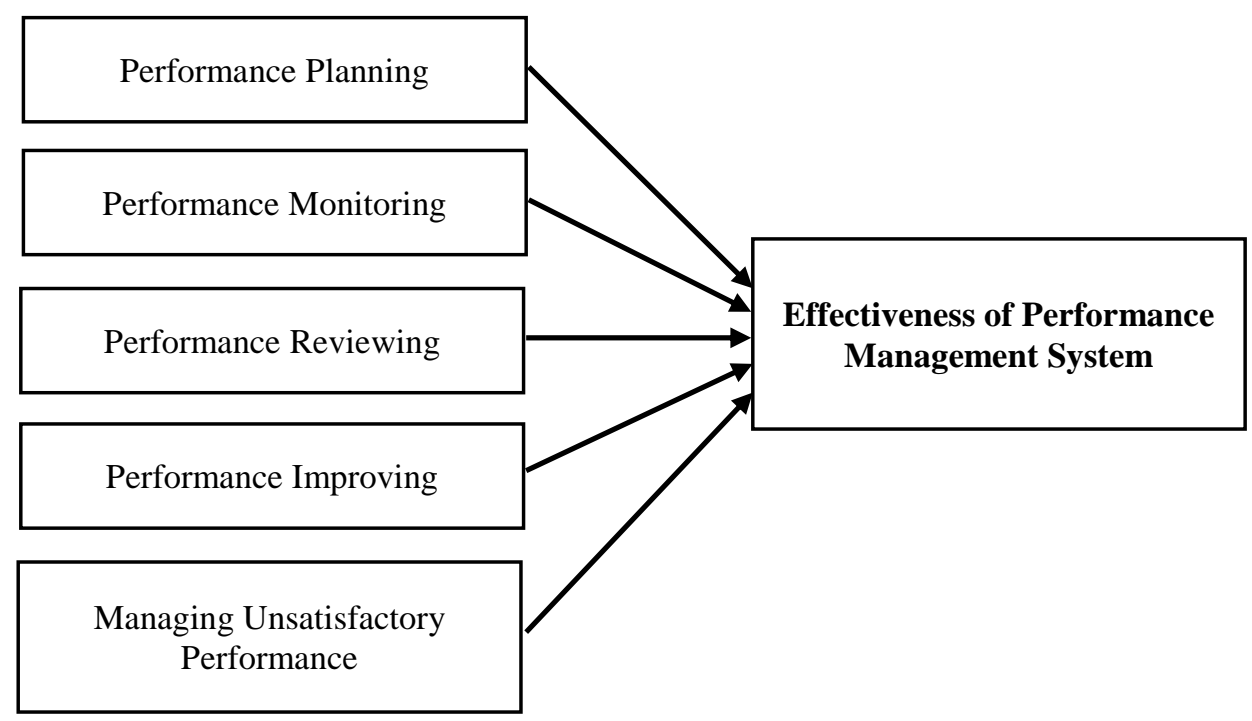

Figure 1: Conceptual Framework of the Study

Source: Authors, 2016

\section{Hypotheses Development}

Following hypothesis were developed in relation with the research objectives.

Overall effectiveness of the performance management system is considered as the dependent variable of this study. Effectiveness of the performance management system will determines the level of accomplishment of its objectives. Effectiveness can be identified as 'the degree to which the system delivers its intended results and simply helping organizations to plan, measure and control their performance' (Bento and Bento, 2006).

Planning performance is an essential element in the performance management process and it can be identified as 'a process of defining the organizational objectives, establishing an overall strategy for achieving these goals and developing a comprehensive hierarchy of plans to integrate and coordinate activities' (Tovey, 2010). It is recommended to develop strategic plans which consist of vision, mission, goals, objectives and the strategies of the organization and these goals will be cascaded down to the individual level. Performance measurements should be developed by aligning with the overall goals and objectives of the organization, as the predetermined goals and objectives are to be achieved through people. In this process, critical success factors and key performance indicators perform a major and critical role. Critical success factors can be identified as the issues and areas that are absolutely critical for an organization to address in achieving its plans (Tovey, 2010). Key performance indicators should be developed based on critical success factors and it is 
recommended to develop these critical success factors based on the opinions given by other stakeholders including customers, suppliers and employees rather than only relying on managers.

Operational plans should be developed in order to figure out the way of achieving the predetermined goals. It is indispensable to refer to key performance indicators and critical success factors in developing operational plans since operational plans explain the means of achieving goals where the key performance indicators denote the specific results expected to be achieved. Operational plans become of utmost importance for implementing the strategies as the plans provide a comprehensive guide to how the organization should work and perform to deliver the end results required by the management. In addition to that, performance planning can be identified as 'a rigorous process of developing strategic plans, corporate operational plans, division, department, business unit operational plans, branch, section, work group and individual operational plans'. As mentioned by Tovey (2001), managers are directly responsible for interpreting the strategic plans into tangible, workable, operational objectives and strategies in relation to resource utilization, delivering the product or service while achieving the allocated budget. Operational plans are utilized as a guidance for daily activities as well.

Setting standards based on the overall objectives of the organization is another essential requirement. In relation to this process, essentially critical success factors and key performance indicators need to be reviewed before setting performance standards. Standards needs to be valid and reliable which means the measure should be adequate to measure the actual result expected. On the other hand, standards should be set based on a mutual agreement between both employees and managers. Apart from that, standards should be realistic, measurable, clearly defined and linked with the strategies and operational plans. This sequential process can be identified as performance planning and this is the base for the entire performance management system. It can be noted that, this relationship is supported by previous studies as well. As suggested by Wong and Snel (2003), Rao (2007), Fox (2010), Daoanis (2012), Qureshi and Hassan (2013) as well as Dewettinck and Dijk (2013), setting performance standards and maintenace of proper and constructive communication with employees are positively related with the effectiveness of the performance management system. Furthermore, Dewettinck and Dijk (2013) and Chenhall (2005) emphasize the significance of fairness of planning performance to ensure the effectiveness of performance management. Hence, the first hypothesis can be developed as follows.

\section{H1: There is a relationship between planning performance and the effectiveness of the performance management system.}

After the completion of performance planning process, individual and team performance should be monitored systematically. The first requirement is studying performance standards. Tovey (2001) further suggests it is 
essential to encourage the employees on self-monitoring. The next requirement is to decide the evidence which should be collected and the time period and this entire process should be conducted in a non-judgmental way. The performance monitoring function is of utmost importance for ensuring the collection of accurate and timely evidence on employee performance where the success of the next step, reviewing performance, depends on the success of the monitoring process. Aligning with this framework, Komati and Zhou (2013) suggest that continuous monitoring and providing frequent constructive feedback directly affects the effectiveness of performance management. In line with these findings, Ferreira and Otley (2009), Biron, et al. (2011) and Mone, et al. (2011) further endorse this relationship by emphasizing the importance of ongoing monitoring and effective feedback. Hence, the second hypothesis can be developed as follows.

\section{H2: There is a relationship between} monitoring performance and the effectiveness of the performance management system.

After the completion of monitoring performance, collected evidence on employee performance should be reviewed. The reviewing performance step consists of two sub elements: performance analysis and performance appraisal. The main purpose of performance analysis is to check whether predetermined performance standards have been met or not. The difference between expected and actual performance should be identified and further, the reasons for these deviations should be identified. Performance analysis should be done in a systematic way as the accuracy of decisions made based on performance information will depend on the accuracy of analysis.

Performance should be appraised once after completing analyzing the performance and it is essential to establish a systematic method of appraising employee performance. Personal development plans can be developed based on the appraisal results in order to ensure the continual growth of the employees.

Performance management system should be adequate to clearly identify the skill gaps of the employees. It is essential to identify the problems related with employee performance, otherwise it will be difficult to solve employee performance related problems. The performance appraisal is not only about evaluation but also providing feedback as well. Performance appraisal step will not be completed if the organization has not discussed the results with the evaluee. Feedback can be identified as 'specific communication facilitated by the appraiser about the existing work performance and planning of the future performance of an individual' (Tovey, 2001). The main two dimenisons which should be considered are the frequency of feedback and process of communication. It is essential for organizations to decide the purpose of performance evaluation as a prerequisite of evaluating performance and that purpose should be communicated to the appraisee as well. This step is essential for planning performance for the future, to identify the performance requirements and career aspirations, deciding on pay increases, succession planning, 
employee motivation and to identify the training needs.

Tovey (2001) explains the need for good preparation for the performance discussion. It should be pre planned in relation to the venue, appointment schedules and providing guidance and support for the employees. In addiiton to that, it is recommended for appraisers to get ready for the discussions backed with evidence on the respective employee's performance. Based on these consequences, it can be argued that reviewing performance is a critical step which should be handled carefully in order to ensure the effectiveness of the entire performance management system. Further to this relationship, Mone, et al. (2011), Daoanis (2012) and Dewettinck and Dijk (2013) suggest that constructive and clear feedback should be provided based on the evaluation results. Aligning with these findings, Qureshi and Hassan (2013) have emphasized the significance of fair and timely appraisal for ensuring the effectiveness of performance management. These relationships are further endosed by Zvavahera (n.d.), Ferreira and Otley (2009) as well. Hence, the next hypothesis can be developed as follows.

\section{H3: There is a relationship between reviewing performance and the effectiveness of the performance management system.}

After completion of reviewing performance, the management is in a position to understand the gap between actual performance and performance standards. This entire process is significant to understand the deviations from the standards. After appraising performance, it is essential to improve the performance as per the requirements. A proper mechanism should be established with the purpose of identifying the development needs based on the appraisal information. The main purpose of this step is to improve identified weak performance. In order to ensure the success of this step, it is essential to provide a thorough training for the appraiser in relation to communicating with employees and improving their performance. As a pre requisite, skill gaps and training needs should be clearly identified. After that, identified training needs should be categorized since it is not practical to provide facilities for fulfilling each and every training need separately due to financial and other restrictions. Furthermore these needs should be linked with specific outputs. Prioritizing training needs in accordance with the significance will be the next step and it should be performed once after categorizing training needs. After prioritization of training needs, relevant and appropriate strategies should be selected based on the requirement and required resources should be allocated for completing the training. Performance improvement plans should be developed and implemented after that. After the implementation, performance of the employees will be monitored in order to ensure the development plans are implemented as expected. Aligning with this relationship, Mone, et al. (2011) have found the significance of correctly identifying the skill gaps and providing training and development opportunities on the effectinvess of performance management. This finding is further 
endorsed by research studies conducted by Haines and St-Onge (2012), Buchner (2007) and Zvavahera where they have identified the contribution provided by constructive traning to improve the effectiveness of performance management. Hence, the next hypothesis can be developed as follows.

\section{H4: There is a relationship between improving performance and the effectiveness of the performance management system.}

A well planned performance management system should facilitate the process of managing unsatisfactory performance. The requirement for managing unsatisfactory performance occurs as the availability of employees who do not put any effort to improve their performance even after providing a personal development plan. It is essential to implement an appropriate mechanism to manage unsatisfactory performance which is important for both appraiser and apraisee. This process is of utmost importance for the organization to achieve its goals and objectives and for the employees for their career development and personal development.

The main components of managing unsatisfactory performance are collecting and analyzing evidence, appraise the evidence and planning for the improvement. Unsatisfactory performance should be managed based on a systematic process. There is a possibility of having different reasons for the poor performance and these reasons should be clearly identified. It is essential to document the unsatisfactory performance and after the documentation, performance counselling meetings should be arranged in order to discuss the performance issues with the employee. At the counseling meeting, employees will be provided opportunity to express their issues and clarifications. Adequate evidence should be collected and documented in order to ensure the reliability of the performance counselling meeting. The expected outputs of counseling meetings are acknowledgment by staff members of the existence of the problem, identifying the causes of the problems, solutions to the problems and agreement on the implementation of the plan. An effective counselling discussion consists of three elements: set up, discussion and documentation. Further discussions will be conducted based on the outputs of the first discussion. Termination of the employment will be the final action which has to be taken against the unsatisfactory performance and there are several other actions which are available to manage unsatisfactory performance which can be started with written warning. This relationship is endorsed by several research findings and it is noted that effectiveness of performance management is effected by the way of managing unsatisfactory performance. Clark (2015) suggests that corrective actions should be taken to manage unsaisfactory performance and should be handled in a construtive manner. Furthermore, Martinez, et al. (2010) suggest that compensation should be properly aligned with performance in order to manage unsatisfactory performance while motivating employees. They further suggest that performance results should be utilized to decide the consequences and necessary actions should be taken 
to manage unsatisfactory performance in order to ensure the success of the performance management process. In line with these suggestions, Daoanis (2012) and Rashidi (2015) have indicated the necessity of taking actions to address the problems related with employee performance with the purpose of improving effectiveness of performance management. Based on that, the next hypothesis can be developed as follows.

H5: There is an impact of mechanisms of managing unsatisfactory

performance and the effectiveness of the performance management system.

\section{Data Collection}

The structured questionnaire method was selected as the method of data collection. The questionnaire was developed by the author based on the literature on performance management. The questionnaire consists of three sections; demographic and job related information, performance management system and effectiveness of the system. As per the requirement of most of the employees, a Google online form was created and sent through emails to collect data for the study. The main objective of this research study was to investigate the effectiveness of performance management systems and the relationship between the performance management system and its effectiveness in garment factories in the Katunayake Export Processing Zone in Sri Lanka. Performance management system is considered as the independent variable for this study. Based on the literature (Tovey, Managing Performance Improvement, 2001), a performance management system consists of five dimensions; planning performance, monitoring performance, reviewing performance, improving performance and managing unsatisfactory performance. Based on this content, these components have been considered as the dimensions of the independent variable (Sub independent variables) and questions were developed in order to measure each dimension.

Effectiveness of the performance management system has been considered as the dependent variable of this research. The Oxford Advanced Learner's Dictionary (2016) mentions effectiveness as 'the degree to which something is successful in producing a desired result; success'. Bento and Bento, (2006) define eeffectiveness of the performance management system as 'the degree to which the system delivers its intended results and simply helping organizations to plan, measure and control their performance'. In order to measure the effectiveness of the system, several authors have selected several measures based on the context of the organization and general criteria. For this purpose, the researcher has selected the explanation proposed by Aguinis (2009) as he has clearly explained the key features of an effective performance management system. Referring to Agunis (2009) fourteen key features of an effective performance management system are considered and these features are considered as the dimensions of the dependent variable, effectiveness of the performance management system. Strategic congruence, thoroughness, practicality, meaningfulness, inclusiveness, specificity, identification of effective and 
ineffective performance, reliability, validity, acceptability and fairness, openness, correctability, standardization and ethicality are the fourteen features introduced by
Aguinis (2009). Furthermore, the questions are developed based on this framework to measure the effectiveness of the performance management system.

Table 1: Dimensions of an Effective Performance Management System

\begin{tabular}{|c|c|}
\hline Characteristic & Definition \\
\hline Strategic congruence & Individual goals are aligned with unit and individual goals \\
\hline \multirow[t]{4}{*}{ Thoroughness } & All employees are evaluated \\
\hline & $\begin{array}{l}\text { Evaluations include performance spanning the entire } \\
\text { review period }\end{array}$ \\
\hline & All major job responsibilities are evaluated \\
\hline & $\begin{array}{l}\text { Feedback is provided on both positive and negative } \\
\text { performance }\end{array}$ \\
\hline \multirow[t]{5}{*}{ Practicality } & It is readily available for use \\
\hline & It is easy to use \\
\hline & Benefits of the system outweigh the cost \\
\hline & It is acceptable to those who use it for decisions \\
\hline & $\begin{array}{l}\text { Only the functions that are under the control of the } \\
\text { employee are measured }\end{array}$ \\
\hline \multirow[t]{3}{*}{ Meaningfulness } & $\begin{array}{l}\text { Evaluation takes place at regular intervals and appropriate } \\
\text { movements }\end{array}$ \\
\hline & $\begin{array}{l}\text { System provides for continuing skill development of } \\
\text { evaluators }\end{array}$ \\
\hline & Results are used for important administrative decisions \\
\hline Specificity & $\begin{array}{l}\text { Detailed guidance is provided to employees about what is } \\
\text { expected of them and how they can meet these } \\
\text { expectations }\end{array}$ \\
\hline $\begin{array}{l}\text { Identification of } \\
\text { effective and } \\
\text { ineffective } \\
\text { performance }\end{array}$ & $\begin{array}{l}\text { The system distinguishes between effective and ineffective } \\
\text { behaviors and results thereby also identifying employees } \\
\text { displaying various levels of performance effectiveness. }\end{array}$ \\
\hline \multirow[t]{2}{*}{ Reliability } & Measures of performance are consistent \\
\hline & Measures of performance are free of errors \\
\hline \multirow[t]{3}{*}{ Validity } & Measures include all critical performance facets \\
\hline & $\begin{array}{l}\text { Measures do not leave out any important performance } \\
\text { facet }\end{array}$ \\
\hline & Measures do not include factors outside employee control \\
\hline $\begin{array}{l}\text { Acceptability and } \\
\text { fairness }\end{array}$ & $\begin{array}{l}\text { Employees perceive the performance evaluation and } \\
\text { reward received relative to the work performed as } \\
\text { fair(distributive justice) }\end{array}$ \\
\hline
\end{tabular}




\begin{tabular}{|c|c|}
\hline Characteristic & Definition \\
\hline & $\begin{array}{l}\text { Employees perceive the procedures used to determine the } \\
\text { ratings and subsequent rewards as fair (procedural justice) }\end{array}$ \\
\hline \multirow[t]{2}{*}{ Inclusiveness } & $\begin{array}{l}\text { Employee input about their performance is gathered from } \\
\text { the employees before the performance appraisal }\end{array}$ \\
\hline & $\begin{array}{l}\text { Employees participate in the process of creating the system } \\
\text { by providing input on how performance should be } \\
\text { measured }\end{array}$ \\
\hline \multirow[t]{4}{*}{ Openness } & $\begin{array}{l}\text { Performance is evaluated frequently and feedback is } \\
\text { provided an ongoing basis }\end{array}$ \\
\hline & $\begin{array}{l}\text { Appraisal meeting is a two way communication process } \\
\text { and not one way communication delivered from the } \\
\text { supervisor to the employee }\end{array}$ \\
\hline & Standards are clear and communicated on an ongoing basis \\
\hline & Communications are factual, open and honest \\
\hline Correctability & $\begin{array}{l}\text { There is an appeal process, through which employees can } \\
\text { challenge unjust or incorrect decisions }\end{array}$ \\
\hline Standardization & $\begin{array}{l}\text { Performance is evaluated consistently across people and } \\
\text { time }\end{array}$ \\
\hline \multirow[t]{3}{*}{ Ethicality } & $\begin{array}{l}\text { Supervisors suppress their personal self interest in } \\
\text { providing evaluation }\end{array}$ \\
\hline & $\begin{array}{l}\text { Supervisors evaluate performance dimensions only for } \\
\text { which they have sufficient information }\end{array}$ \\
\hline & Employee privacy is respected \\
\hline
\end{tabular}

Source: Agunis, H. (2009) - Performance Management

\section{Demographic Variables}

The questionnaire has been designed by including several demographic variables which are not directly relevant to the main research problem. But, these demographic variables are significant to analyze the variations of the way they perceive the existing performance management system and its effectiveness. Especially these variables are important to differentiate perceptions in terms of managerial level, education level, experience and age of the employees.

\section{Reliability Statistics}

Data reliability measures research variables' homogeneity or the extent to which each indicator of a concept converges to some common meaning. Conbach's Alpha value was used to measure the reliability of the measures. Referring to table 2 , it can be noted that reliability of the measures are ensured where the Cronbach's alpha values are around 0.7 . 
Table 2: Reliabilities Statistics

\begin{tabular}{|l|c|}
\hline \multicolumn{1}{|c|}{ Variable } & Cronbach's Alpha \\
\hline Performance Planning & 0.650 \\
\hline Performance Monitoring & 0.688 \\
\hline Performance Review & 0.627 \\
\hline Managing Unsatisfactory Performance & 0.659 \\
\hline Improving Performance & 0.752 \\
\hline Performance Management System & 0.790 \\
\hline Effectiveness of Performance Management System & 0.823 \\
\hline
\end{tabular}

Source: Survey data, 2016

\section{Hypothesis Testing}

Hypotheses were tested based on the $p$ value.

Table 3: Pearson's Correlation Coefficient values

\begin{tabular}{|l|c|c|c|}
\hline \multirow{2}{*}{} & \multicolumn{3}{|c|}{$\begin{array}{c}\text { Effectiveness of the Performance } \\
\text { Management system }\end{array}$} \\
\cline { 2 - 4 } & $\begin{array}{c}\text { Pearson's } \\
\text { Correlation }\end{array}$ & $\begin{array}{c}\text { Sig. (2- } \\
\text { tailed) }\end{array}$ & $\begin{array}{c}\text { Correlation is } \\
\text { significant at }\end{array}$ \\
\hline Planning performance & 0.529 & 0.000 & 0.01 \\
\hline Monitoring performance & 0.631 & 0.000 & 0.01 \\
\hline Reviewing performance & 0.563 & 0.000 & 0.01 \\
\hline Improving performance & 0.283 & 0.020 & 0.05 \\
\hline $\begin{array}{l}\text { Managing unsatisfactory } \\
\text { performance }\end{array}$ & 0.278 & 0.023 & 0.05 \\
\hline
\end{tabular}

Source: Survey data, 2016

According to the table 3 , it can be stated that, there is a moderate positive correlation (0.529) between planning performance and effectiveness of the performance management system which is statistically significant at one percent of error level. Furthermore, it can be identified that in-between monitoring performance and effectiveness of the performance management system has positive relation (0.631) which is significant at 99\% confidence level. Also, it can be claimed that in-between reviewing performance and effectiveness of the performance management system has positive relation $(0.563)$ at $99 \%$ level of confidence. Furthermore it can be claimed that, there is a week positive correlation ( 0.283 ) between improving performance and effectiveness of the performance management system at 95\% confidence level.

Supported with the statistical results given in table 3 , it can be identified that 
the correlation between managing unsatisfactory performance and effectiveness of the performance management system has positive value (0.278) at $95 \%$ level of confidence level.

Based on the hypothesis testing, it can be identified that all five hypotheses are supported and planning performance, monitoring performance, reviewing performance, improving performance and managing unsatisfactory performance have positive correlation with effectiveness of performance management system.
Further to above findings, Regression analysis was conducted in order to identify the impact of the elements of performance management system on effectiveness of performance management system. Multiple regression analysis was used to describe the way in which independent variables are related to the dependent variable. In addition to that, it can be used to derive a linear model or mathematical equation to predict successive data points as better estimations.

Table 4: Model Summary

\begin{tabular}{|c|c|c|c|c|}
\hline Model & $\mathbf{R}$ & $\begin{array}{c}\mathbf{R} \\
\text { Square }\end{array}$ & $\begin{array}{c}\text { Adjusted R } \\
\text { Square }\end{array}$ & $\begin{array}{c}\text { Std. Error of the } \\
\text { Estimate }\end{array}$ \\
\hline 1 & $.670^{\mathrm{a}}$ & .449 & .432 & .18493 \\
\hline
\end{tabular}

a. Predictors: (Constant), Reviewing Performance, Monitoring Performance

b. Dependent Variable: Effectiveness of the performance Management System Source: Survey data, 2016

Adjusted R square value for appropriate linear regression model is around 0.432 with lower estimation of standard deviation error value (0.18493) (Table 4). As mentioned in the above table 1, approximately forty three percent of the variation of the dependent variable is explained by the two independent variables (reviewing performance and monitoring performance).

Table 5: ANOVA

\begin{tabular}{|l|c|c|c|c|c|}
\hline Model & $\begin{array}{c}\text { Sum of } \\
\text { Squares }\end{array}$ & Df & $\begin{array}{c}\text { Mean } \\
\text { Square }\end{array}$ & F & Sig. \\
\hline Regression & 1.783 & 2 & .892 & 26.074 & $.000^{\mathrm{b}}$ \\
\hline Residual & 2.189 & 64 & .034 & & \\
\hline Total & 3.972 & 66 & & & \\
\hline
\end{tabular}

a. Dependent Variable: Effectiveness of the performance Management System

b. Predictors: (Constant), Reviewing Performance, Monitoring Performance

Source: Survey data, 2016 
Analysis of variance (ANOVA) table for predicted linear regression line is significant at ninety five percent of confidence interval.

\section{Table 6: Regression Coefficients}

\begin{tabular}{|c|c|c|c|c|c|}
\hline \multirow{2}{*}{ Model } & \multicolumn{2}{|c|}{$\begin{array}{l}\text { Unstandardized } \\
\text { Coefficients }\end{array}$} & \multirow{2}{*}{$\begin{array}{c}\text { Standardized } \\
\text { Coefficients }\end{array}$} & \multirow{2}{*}{$\mathrm{t}$} & \multirow{2}{*}{ Sig. } \\
\hline & B & $\begin{array}{l}\text { Std. } \\
\text { Error }\end{array}$ & & & \\
\hline (Constant) & 1.371 & .373 & & 3.671 & .001 \\
\hline Planning performance & .078 & .086 & .114 & .914 & .364 \\
\hline Monitoring performance & .203 & .067 & .419 & 3.042 & .003 \\
\hline Reviewing performance & .150 & .090 & .199 & 1.670 & .100 \\
\hline $\begin{array}{l}\text { Managing unsatisfactory } \\
\text { performance }\end{array}$ & .047 & .082 & .059 & .570 & .571 \\
\hline Improving performance & .106 & .062 & .182 & 1.720 & .091 \\
\hline
\end{tabular}

Dependent Variable: PMS Effectiveness

Source: Survey Data, 2016

\section{Table 7: Regression Coefficients}

\begin{tabular}{|l|c|c|c|c|c|}
\hline \multirow{2}{*}{ Model } & \multicolumn{2}{|c|}{$\begin{array}{c}\text { Unstandardized } \\
\text { Coefficients }\end{array}$} & $\begin{array}{c}\text { Standardized } \\
\text { Coefficients }\end{array}$ & \multirow{2}{*}{ T } & \multirow{2}{*}{ Sig. } \\
\cline { 2 - 4 } & $\mathrm{B}$ & $\begin{array}{c}\text { Std. } \\
\text { Error }\end{array}$ & Beta & & \\
\hline B Constant) & 1.947 & .248 & & 7.840 & .000 \\
\hline $\begin{array}{l}\text { Monitoring } \\
\text { Performance }\end{array}$ & .222 & .057 & .458 & 3.909 & .000 \\
\hline $\begin{array}{l}\text { Reviewing } \\
\text { Performance }\end{array}$ & .214 & .088 & .283 & 2.418 & .018 \\
\hline
\end{tabular}

a. Dependent Variable: Effectiveness of the performance Management System Source: Survey data, 2016

Regression analysis was conducted further using 'backward regression' and only two independent variables were found to fit with the model. Based on the data analysis, it was found that the effectiveness of the PM system in garment factories in the Katunayake Export Processing Zone is at a good level. Based on the data analysis, effectiveness of the performance management system is positively related with planning performance
( 0.529 at $99 \%$ confidence level), A moderate positive relationship was found between monitoring performance and effectiveness of performance management systems (0.631 at $99 \%$ confidence level), a moderate positive relationship between reviewing performance and effectiveness of the system (0.563 at $99 \%$ confidence level), a weak positive relationship was figured out between the measures taken by the organization 
in order to improve employee performance and effectiveness of the performance management system ( 0.283 at $95 \%$ confidence level) and a weak positive relationship was found between the mechanisms which were implemented by the organizations to manage unsatisfactory performance and the effectiveness of the performance management system ( 0.278 at $95 \%$ confidence level). These relationships were in line with the previous studies conducted by Wong and Snel (2003), Chenhall (2005), Rao (2007), Fox (2010), Daoanis (2012), Qureshi and Hassan (2013) and Dewettinck and Dijk (2013), Ferreira and Otley (2009), Biron et al. (2011), Mone, et al. (2011) and Komati and Zhou (2013) Taylor et al. (1984), Zvavahera (n.d.), Buchelt (n.d.), Qureshi and Hassan (2013), Buchner (2007), Haines and St-Onge (2012), Clark (2015) and Rashidi (2015) .

\section{Discussion}

Based on the data analysis, it was found that the effectiveness of the performance management system in garment factories in the Katunayake Export Processing Zone is at a good level. Based on the data analysis, effectiveness of the performance management system is positively related with planning performance ( 0.529 at $99 \%$ confidence level). It emphasizes a moderate positive relationship between planning performance and the overall effectiveness of performance management system. It can be noted that, this found relationship is in line with the previous studies conducted by Wong and Snel (2003), Chenhall (2005), Rao (2007), Fox (2010),
Daoanis (2012), Qureshi and Hassan (2013) and Dewettinck and Dijk (2013) where they have emphasized the significance of various aspects of planning performance to ensure the effectiveness of performance management.

The second hypothesis was supported by statistical analysis results and a moderate positive relationship was found between monitoring performance and effectiveness of performance management systems ( 0.631 at $99 \%$ confidence level), which is conformed with the literature where, Ferreira and Otley (2009), Biron et al. (2011), Mone, et al. (2011) and Komati and Zhou (2013) have highlighted the contribution of continuous monitoring and providing frequent constructive feedback on the effectiveness of performance management.

Referring to Farr (1993), Rao (2007) mentions that informal or day-to-day feedback is more important than feedback that occurs during the annual or semi-annual performance appraisal session in terms of its impacts on work performance and attitudes. Further to this finding, Taylor et al. (1984) proposed that regular feedback should bring about closer agreement over performance standards between employees and the organization (that is, the manager) (Rao, 2007).

The data analysis showed that there is a moderate positive relationship between reviewing performance and effectiveness of the system $(0.563$ at 99\% confidence level). This positive relationship is in line with the findings of the previous studies, where Ferreira and Otley (2009), Mone, et al. (2011), Daoanis (2012), Dewettinck and Dijk 
(2013), Zvavahera (n.d.), Buchelt (n.d.) and Qureshi and Hassan (2013) suggest the contribution of constructive and clear feedback on the evaluation results and the fair and timely appraisal for ensuring the effectiveness of performance management.

A weak positive relationship was figured out between the measures taken by the organization in order to improve employee performance and effectiveness of the performance management system (0.283 at $95 \%$ confidence level). This found positive relationship is aligned with the previous studies conducted by Buchner (2007), Mone, et al. (2011), Haines and St-Onge (2012), and Zvavahera (n.d.) but, the relationship has denoted a weak relationship where some of these previous studies indicated a strong positive relationship.

Based on the data analysis result, a weak positive relationship was found between the mechanisms which were implemented by the organizations to manage unsatisfactory performance and the effectiveness of the performance management system (0.278 at $95 \%$ confidence level). However, based on the previous studies conducted by Daoanis (2012), Clark (2015) and Rashidi (2015) managing unsatisfactory performance has been indicated as one of the key factors which effect on the effectiveness of performance management. But in this particular study, it has a weak positive relationship with the effectiveness of the system.

Based on the regression analysis, it was found that, effectiveness of the performance management system was influenced by monitoring performance and reviewing performance by considering the regression model with $44.9 \%$ of the model adequacy from this research. Based on the statistical results, the researcher has concluded that the effectiveness of the performance management system had a linear contribution from monitoring performance (0.222) and reviewing performance (0.241) separately. Based on that, it can be inferred that monitoring and reviewing performance are the key determinants of the effectiveness of the performance management systems in garment factories in the Katunayake Export Processing Zone in Sri Lanka.

There was an open ended question in the questionnaire to add the views on the current performance management system and one managerial level employee at one of the selected companies has commented on their current system. "The company that I belong to use a decent performance management system called ITM (Internal Talent Management). It helps supervisors to access past performance records of subordinates. Also, details regarding subordinates are updated in ITM that can be accessed by the supervisor of the employee. So, it is effective and useful. Area what I feel should be improved in the ITM is, during the feedback session, there is only one to one (or one to many) discussions but, not shared feedback of each and every point in the ITM system". This comment further endorses the findings of the research where the participant has specifically mentioned regarding the feedback discussions which is a critical element of reviewing performance. 
It was found that there is a slight difference between the ratings on the performance management system and its effectiveness between managerial and executive level employees and this situation can be explained by Signaling theory by Spence (1973). As posited by Murray (1991), signaling theory suggests that 'people need tangible information to help them understand the organization's interests or future prospects' (Biron, et al., 2011). Based on this theory, Biron, et al. (2011) further claim that performance management suggests a number of observable formal practices which transmit important signals to help employees to sense the organizational expectations and what really organization values. Based on this background of Signalling theory, the variations between the perception of managerial and executive employees on performance management system can be explained. Sometimes employees may misunderstand the signals transmitted by the managers regarding different practices. Hartog, et al. (2004) suggest that employees evaluate the human resource practices based on their perception regarding the signals provided by the organization. Especially, when the performance management system is taken into consideration, it is clear that the same set of practices can be interpreted by different parties in different ways based on the signals they receive. In this kind of a scenario, there is a possibility of ranking the same performance managament system and its effectiveness in two different ways.
Simply in this situation, the values provided by managerial employees are slightly high compared with the executive employees' values.

\section{Conclusion}

Managing employee performance has become more challenging for the contemporary organizations owing to severe competition in the market, globalization and changes of the business environment. As each and every organization is striving for the accomplishment of their goals and objectives through their workforce, managing human resource is considered as a sustainable source of competitive advantage. Managing employee performance aligning with the strategic and operational goals of the organization is of utmost importance for any organization. As per the main objective of this research, performance management system and effectiveness of the system were investigated and positive relationships were found between different practices of performance management and the contribution of those to system effectiveness. In addition to that, monitoring and reviewing performance were noted as the most critical steps to be handled carefully as these two steps have a greater influence on the effectiveness of the system. Hence, it can be recommended for the organizations to follow a systematic process for managing employee performance and specifically focus on monitoring and reviewing employee performance. 


\section{References}

Aguinis, H., \& Pierce, C. (2008). Enhancing the Relevance of Organizational Behavior by Embracing Performance Management Research. Journal of Organizational Behavior, 29(1), 139-145.

Agunis, A. (2009). Performance Management. Dorling Kindersley Pvt. Ltd., India.

Ahmad, M. (2011). Impact of Organizational Culture on Performance Management Practices in Pakistan. Business Intelligence Journal, 5(1), 50-55.

Ammons, D., \& Roenigk, D. (2015). Performance Management in Local Government: Is Practice Influenced by Docrine? Public Management and Performance Review, 38, 514-541.

Armstrong, M. (2006). Armstrong's Handbook of Performance Management. Kogan Page Limited.UK.

Armstrong, M. (2014). Handbook of human resource management practice (13 ed.). London, UK: Kogan Page.

Barney, J. B. (1986). Organizational Culture: Can It Be a Source of Sustained Competitive Advantage? The Academy of Management Review, 11(3), 656665.

Barney, J., Wright, M., \& Ketchen, D. (2001). The resource-based view of the firm: Ten years after 1991. Journal of Management, 27, 625-641.

Bartłomiej, N. (2008). Requirements for Performance Management Systems: A Delineation of the Comprehensive Set of Criteria. European Financial and Accounting Journal, 3(3).

Bawole, J., Hossain, F., Domfeh, K., Bukari, H., \& Sanyare, F. (2013). Performance Appraisal or Praising Performance? The Culture of Rhetoric in Performance Management in Ghana Civil Service. International Journal of Public Administration, 36(13), 953-962. doi:10.1080/01900692.2013.773030

Belogolovsky, E., \& Bamberger, P. (2014). Signaling in Secret: Pay for Performance and the Incentive and Sorting Effects of Pay Secrecy. Academy of Management Journal, 57(6), 1706-1733. doi:org/10.5465/amj.2012.0937

Bento, A., \& Bento, R. (2006). Factors Affecting the Outcomes of Performance Management Systems. Journal of Information Technology Management, XVII, 23-32.

Biron, B., Farndale, E., \& Paauwe, J. (2011). Performance management effectiveness: lessons from world-leading firms. The International Journal of Human Resource Management, 1294-1311. doi:10.1080/09585192.2011.559100

Board, E. D. (2016). Industry Capability Report. 
Boipono, M., Tsomele, T., \& Mogadime, R. (2014). Implementation of Performance Management System (Pms) in Schools: Success Factors. International Journal of Research in Applied, Natural and Social Sciences, 2(5), 189-194.

Bouckaert, G., \& Peters, B. (2002). Performance Measurement and Management. Public Performance: A Conceptual Framework \& Management Review, 25(4), 356-362.

Bowen, D., \& Ostroff, C. (2004). Understanding HRM-Firm Performance Linkages: The Role of the "Strength" of the HRM The Academy of Management Review. The Academy of Management Review, 29(2), 203-221. Retrieved from http://www.jstor.org/stable/20159029.

Buchelt, B. (n.d.). Performance Management as Modern Appraoch to Employees' Appraisal in Healthcare Entities. 75-92.

Buchner, T. M. (2007). Performance management theory: A look from the performer's perspective with implications for HRD. Human Resource Development International, 10(1), 59-73. doi:10.1080/13678860601170294

Clark, P. (2015). Bringing Meaningful Change to Performance Management. Association for Talent Development.

Daghfous, A. (2012). How To Make Knowledge Management A Firm’s Core Capability. Journal of Knowledge Management Practice.

Daoanis, L. (2012). Performance Appraisal System: It's Implication To Employee Performance. 2(3), 55-62.

DeNiSi, A. (2011). Managing Performance to Change Behavior. Journal of Organizational Behavior Management, 31(4), 262-276. doi:10.1080/01608061.2011.619414

Dewettinck, K., \& Dijk, H. (2013). Linking Belgian employee performance management system characteristics with performance management system effectiveness: exploring the mediating role of fairness. The International Journal of Human Resource Management, 24(4), 806-825. doi:10.1080/09585192.2012.700169

Dooren, W. V. (2011). Better Performance Management. Public Performance and Management Review, 34(3), 420-433.

Ellis, I., \& Onyeizube, C. (2011). Performance Management as an Imperative Foreffective Performance in Delta State of Nigerian Public Owned Organizations. Sacha Journal of Policy and Strategic Studies, 1(2), 46-54.

Export Development Board, S. L. (2016). Industrial Capability Report- Sri Lankan Apperal Sector. 
Fox, A. (2010). The Current State of Performance Management and Career Development. Hewitte Associates LLC.

Haines, V., \& St-Onge, S. (2012). Performance management effectiveness: practices or context? The International Journal of Human Resource Management, 23(6), 1158-1175. doi:10.1080/09585192.2011.561230

Hartog, D., Boselie, P., \& Paauwe, J. (2004). Performance Management: A Model and Research Agenda. Applied Psychology: An International Review, 53(4), 556 -569 .

Heinrich, C. (2002). Outcomes-Based Performance Management in the Public Sector: Implications for Government Accountability and Effectiveness. Public Administration Review, 62(6), 712-725.

Hewitt, A. (2010). The Current State of Performance Management and Career Development. Retrieved from http://www.aon.com/attachments/thoughtleadership/Hewitt_Survey_Results_PerfMgmtCareerDevSV10.pdf

Hofer, C., \& Schendel, D. (1978). Strategy Formulation : analytical concepts. St. Paul: West Pub. Co.

Huselid, M. (1995). The Impact of Human Resource Management Practices on Turnover, Productivity and Corporate Financial Performance. Academy of Management Journal, 38(3), 635-672.

Hussain Ali, M., \& Opatha, H. (2008). Performance Appraisal System and Business Performance: An Empirical Study in Sri Lankan Apparel Industry. Sri Lankan Journal of Human Resource Management, 2(1), 74-90.

Jaksic, M., \& Jaksic, M. (2013). Performance Management and Employee Satisfaction. Montenegrin Journal of Economics, 9(1).

Kagaari, J. (2011). Performance management practices and managed performance: the moderating influence of organisational culture and climate in public universities in Uganda. Measuring Business Excellence, 15(4), 36 - 49. doi:doi.org/10.1108/13683041111184099

Kagaari, J., Munene, J., \& Ntayi, J. (2010). Performance management practices, employee attitudes and managed performance. International Journal of Educational Management, 24(6), 507 - 530.

Kagaari, J., Munene, J., \& Ntayi, J. (2010). Performance management practices, employee attitudes and managed performance. International Journal of Educational Management, 24(6), 507 - 530. doi:doi.org/10.1108/09513541011067683

Karasek, R., \& Bryant, P. (2012). Signaling Theory: Past, Present, and Future. Academy of Strategic Management Journal, 11(1), 91-99. 
Kelegama, S., \& Epaarachchi, R. (2003). Garment industry in Sri Lanka. International Labor Organization.

Komati, M., \& Zhou, Y. (2013). What are the most efficient and effective practices surrounding performance management? Cornell University.

Kottawatta, K. H. (2007). Impact of Attitudinal Factors on Job Performance of Executives. Sri Lankan Journal of Human Resource Management, 1(1).

Lanarolle, W., Perera, T., \& Yapa, T. (2014). Performance Improvement Best Practices Applicable to the Sri Lankan Apparel Industry. International Conference on Management and Economics. Faculty of Management and Finance, University of Ruhuna, Sri Lanka.

Martinez, V., Pavlov, A., \& Bourne, M. (2010). Reviewing Performance : an analysis of the structure and functions of performance management reviews. Production Planning and Control, 21(1), 70-83.

Mehmood, S., Ramzan, M., \& Akbar, M. (2013). Managing Performance through Reward System. Journal of Education \& Research for Sustainable Development, 1(1).

Mensah, W., \& George, B. (2015). Performance Management in the Public Sector: An Action- Research Based Case Study in Ghana. Journal of Applied Economics and Business Research, 5(2), 97-111.

Mone, E., Eisinger, C., Guggenheim, K., Price, B., \& Stine, C. (2011). Performance at the Wheel: Driving Employee Engagement in Organizations. Journal of Business Psychology, 26, 205-212. doi:10.1007/s 10869-011-9222-9

Moyniham, D. (2008). In The dynamics of performance management: Constructing information and reform. Washington, DC: Georgetown University Press.

Moynihan, B. (2005). Goal-Based Learning and the Future of Performance Management. Public Administration Review, 65(2), 203-216. Retrieved from http://www.jstor.org/stable/3542554

Moynihan, D., \& Pandey, S. (2010). The Big Question for Performance Management: Why Do Managers Use Performance Information? Journal of Public Administration Research and Theory.

Nankervis, A., Stanton, P., \& Foley, P. (2012). Exploring the Rhetoric and Reality of Performance Management Systems and Organisational Effectiveness Evidence from Australia,. Research and Practice in Human Resource Management, 20(1), 40-55.

Poister, T., Pasha, O., \& Edwards, L. (2013). Does Performance Management Lead to Better Outcomes? Evidence from the U.S. Public Industry. Public Administration review, 73(4), 625-636. 
Pollitt, C. (2005). Performance Management in Practice: A Comparative Study of Executive Agencies. Journal of Public Administration Research and Theory, 25-44. doi:10.1093/jopart/mui045

Pulakos, E. (2009). Performance Magement, A New Approach for Driving Business Results. John Wiley \& Sons Ltd, UK.

Qureshi, A., \& Hassan, M. (2013). Impact of performance management on the organisational performance:An analytical investigation of the business model of McDonalds. International Journal of Academic Research in Economics and Management Sciences, 2(5).

Rao, A. (2007). Effectiveness of performance management systems: an empirical study in Indian companies. International Journal of Human Resource Management, 18(10), 1812-1840. doi:10.1080/09585190701570973

Rashidi, R. (2015). A Review 0f Performance Management System. International Journal of Academic Research, 7(1). doi:10.7813/2075-4124.2015/7-1/B.36

Rishipal, M. (2013). Performance Management and Employee Loyalty. Global Journal of Management and Business Research Administration and Management, 13(1).

Robbins, S., \& Coulter, M. (2012). Management. USA: Pearson Education.

Robbins, S., \& Judge, T. (2013). Organizational Behaviour. Pearson Education Inc., USA.

Schuler, R., \& Jackson, S. (2005). A Quarter - Century Review of Human Resource Management in the U.S.A.: The Growth in Importance of the International Perspective. 16(1).

Sekaran, U., \& Bougie, R. (2010). Research Methods for Business (5 ed.). John Wiley $\&$ Sons Ltd.

Shields, J., Brown, M., Kaine, S., Dolle-Samuel, C., Johns, R., North-Samardzic, A., Plimmer, G. (2007). Managing Employee Performance \&Rewad: Concepts, Practices, Strategies. Melbourne, Australia: Cambridge University Press.

Smith, A., \& Rupp, W. (2002). Communication and loyalty among knowledge workers: a resource of the firm theory view. Journal of Knowledge Management, 6(3), 250-261.

Sridarran, L. (2016). Impact of Work Place Stress on Employees' Job Performance: Special. International Journal of Business \& Management, 4(3).

Stanton, P., \& Nankervis, A. (2011). Linking strategic HRM, performance management and organizational effectiveness: perceptions of managers in Singapore. Asia Pacific Business Review, 17(1), 67-84. doi:10.1080/13602381003790382 
Taylor, J., \& Baines, C. (2012). Performance management in UK universities: implementing the Balanced Scorecard. Journal of Higher Education Policy and Management, 34(2), 111-124. doi:10.1080/1360080X.2012.662737

Taylor, M., Masterson, S., Renard, M., \& Tracy, K. (1998). Managers' Reactions to Procedurally Just Performance Management Systems. The Academy of Management Journal, 41(5), 568-579. Retrieved from http://www.jstor.org.

Tovey, M. (2001). Managing Performance Improvement. Pearson Education, Australia.

Tovey, M., Uren, M., \& Sheldon, N. (2010). Managing Performance Improvement. Pearson Australia. Retrieved from https://books.google.lk/books.

Tovey, M., Uren, M., \& Sheldon, N. (2010). Performance Management. Australia: Pearson Australia.

Vernadat, F., Shah, L., Etienne, A., \& Siadat, A. (2013). VR-PMS: a new approach for performance measurement and management of industrial systems. International Journal of Production Research, 51(23-24), 7420-7438. Retrieved from http://dx.doi.org/10.1080/00207543.2012.752593

Walker, R., Damanpour, F., \& Devece, C. (2010). Management Innovation and Organizational Performance: The Mediating Effect of Performance Management. Journal of Public Administration Research and Theory, 21, 367-386. doi:10.1093/jopart/muq043

Wang, X. (2007). Learning, job satisfaction and commitment: an empirical study of organizations in China. Chinese Management Studies, 1(13), 167-179.

Wernerfelt, B. (1984). A Resource-Based View of the Firm. Strategic Management Journal, 5(2), 171-180.

Wholey, J. (1999). Performance-Based Management: Responding to the Challenges. Public Productivity \& Management Review, 22(3), 288-307. Retrieved from http://www.jstor.org/stable/3380705

Wong, Y., \& Snell, R. (2003). Employee Workplace Effectiveness: Implications for Performance Management Practices and Research. Journal of General Management, 29(2), 53-69.

Wright, P., Dunford, B., \& Snell, S. (2001). Human resources and the resource based view of the firm. Journal of Management, 27, 701-721.

Wrigth, P., Dunford, B., \& Snell, S. (2001). Human resources and the resource based view of the firm. Journal of Management, 27, 701-721.

Yetano, A., \& Matsuo, T. (2015). Are Changes Effective in Performance Management? An Analysis of Japanese Agencies. International Journal of Public Administration, 38(8), 573-585. doi:10.1080/01900692.2014.949752 
Rathnakara \& Arachchige, KJHRM 2020, 15(01)

Zvavahera, P. (n.d.). An evaluation of the effectiveness of performance management systems on service delivery in the Zimbabwean civil service. Journal of Management and Marketing Research. 